\title{
Needs Analysis of English Materials for Islamic Economics Students
}

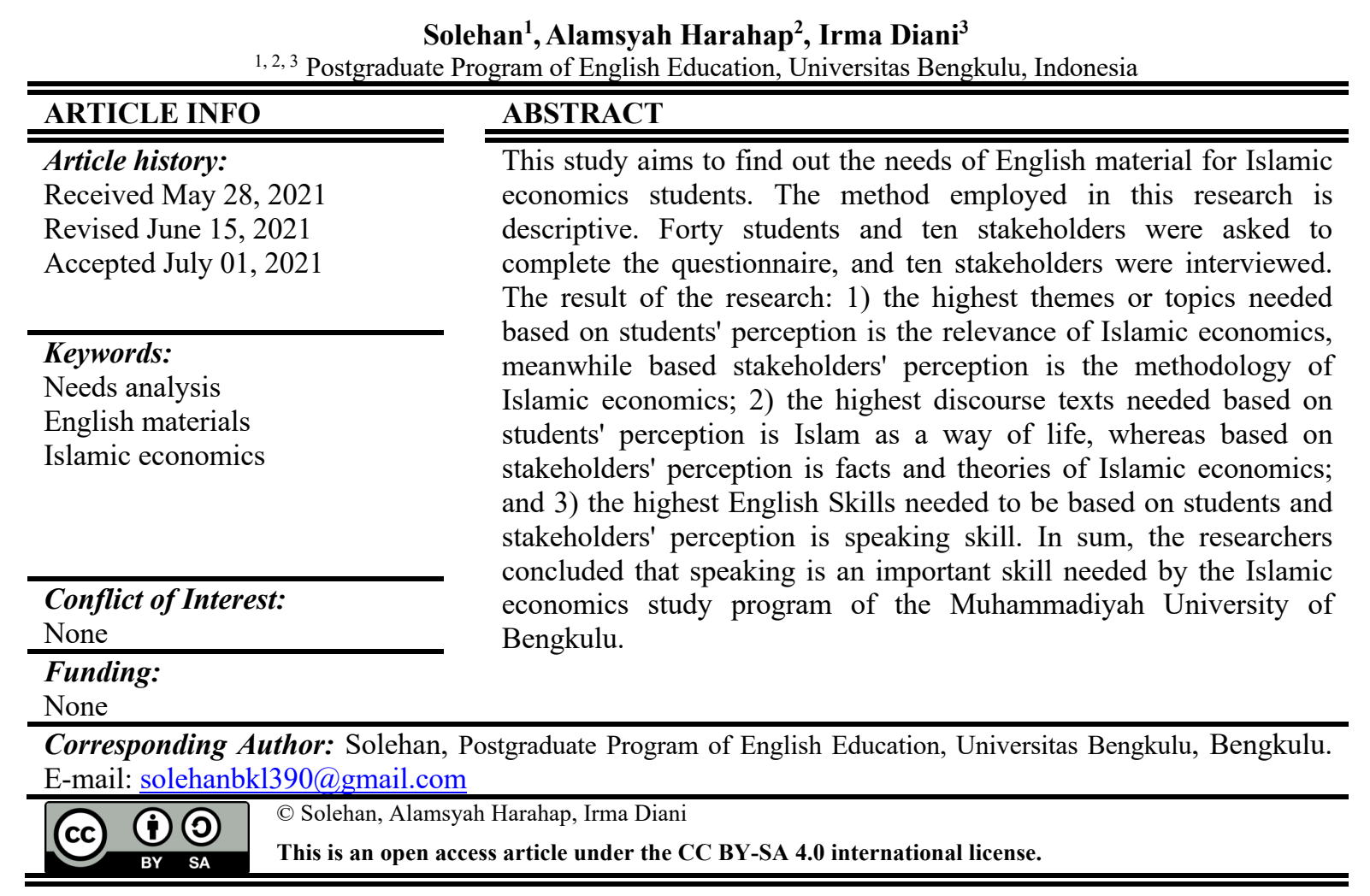

\section{Introduction}

Facing the ASEAN Economic Community (AEC), Indonesian Islamic economics stakeholders must prepare themselves to be the references for Islamic economics, at least in the ASEAN society. Concerning this issue, higher educational institutions should produce learning outcomes correlated with job competencies needed in their future working world. This condition indeed has been a big task for the higher institution to deal with.

In response to this issue, Muhammadiyah University of Bengkulu has organized the program study of Islamic economics since 2013 to prepare the human resources in Islamic economics. The fresh graduate students of the program are expected to master the skills of their expertise. Besides, English becomes very important since most job vacancies put English proficiency, both written and spoken, as one of the requirements. Moreover, the development of the global communication and information era brings tough competition among job seekers. Therefore, the students will get advantages if they master English of their expertise. In terms of education, English is always considered one of the subjects to be taught in almost all levels of education. Considering the facts above, English has become an important skill to master by students of Islamic economics study program.

In practice, English courses in non-English departments of higher education in Indonesia have been popularly called general English courses included in one of the general courses (MKU) offered and taught to first-year students in the first two semesters (Alwasilah, 1999; Kusni, 2007). Initially, as English is included as one of the general courses, for quite a long term, there has been the confusion of teaching English for undergraduate students, whether as general English or English with special needs until the government enacted the regulation of classifying curriculum in higher education as local (institutional) curriculum and national curriculum (Kusni, 2007).

There is a possibility that the English learning materials of the Islamic economics study program of the Muhammadiyah University of Bengkulu are not related to the students' needs because English lecturers 
usually teach their students by using available textbooks. However, the English learning materials suitable for the student's needs are not always available.

The Islamic economics study program students cannot get the appropriate exposure to English which is needed for their future because there are no considerations about the target situation and the target needs of the students. Moreover, the texts or inputs are taken from general English coursebooks. As a result, the course books contain very general input which is not contextualized for the Islamic economics study program.

Furthermore, the English learning materials should be designed based on the students' needs to support the English learning process. Besides, the learning materials should be contextualized based on their study program. The importance of needs analysis is mentioned by Hutchinson and Waters (1987), Jordan (1997), and Robinson (1990) when saying that any approach to course design should start with some analysis of target needs, present situation, language, etcetera. With the data obtained, it will be possible to formulate 'general aims' and more 'specific objectives' as intended outcomes.

Some studies have been conducted on the needs analysis in Indonesia. First, Araminta \& Halimi (2015) researched analyzing the English needs of undergraduate engineering students at the University of Indonesia. The results show that English proficiency was compulsory for an engineer to get a job, especially in a multinational company. Nevertheless, the need for English language learning was regarded as not significant. A win-win solution for this can be to provide an optional course on English for Professional Purposes as a collaboratively taught course between English teachers or needs analysis practitioners and lecturers in the engineering field.

Second, Miyake \& Tremarco (2005) researched the needs of the undergraduate, postgraduate, and professional nurses through questionnaires and interviews based on a needs analysis to discuss the implications for EFL teachers. Ana's analysis of the results suggested that social English is more important as it enables the nurse to communicate with patients and enriches them as individuals. It also insinuated that classroom activities should promote confidence in using social-communicative English throughout a course focusing on speaking and listening.

Third, Khalik (2014) conducted research designing a syllabus and adapting materials based on students 'needs. In order to achieve this objective, needs analysis of the students was carried out in advance. The results of the target situation analysis also indicate that the primary purpose of the students of Economic Faculty, Universitas "45" Makassar in learning ESP is to enable them to read and understand books related to economics written in English that are available in libraries. Based on this fact, the researcher tried to design a syllabus that integrated reading skills, vocabulary acquisition, and mastery of English grammar. Further, the materials were arranged based on the students' topics of interest/priority.

Based on the description and the problem above, the writer will research to investigate the English materials needed by students of the Islamic economics study program and the topic of each skill that the students need to prepare for their career in Islamic economics.

\section{Literature Review}

\subsection{English for Specific Purposes (ESP)}

Judd (1981) states that English as a Language of Wider Communication (ELWC) refers to an environment in which English serves no intra-country uses and is used for international communicative purposes. Therefore, many people need to use English for scientific, technical, and commercial purposes, which are popularly called "English for Specific Purposes" (ESP).

Notably, three reasons are contributing to the emergence of all ESP, which is 1) the expansion of demand for English to suit particular needs, 2) development in the field of linguistics, and 3) educational psychology (Hutchinson and Waters, 1987).

The expansion of demand for English to suit particular needs: Hutchinson and Waters (1987) note that there are two critical historical periods of ESP. First, the end of the Second World War brought with it an "...age of enormous and unprecedented expansion in scientific, technical and economic activity on an international scale for various reasons, most notably the economic power of the United States in the postwar world, the role (of international language) fell to English..." (p.6). Second, the Oil Crisis of the early 1970s resulted in Western money and knowledge flowing into the oil-rich countries. The language of this knowledge was English.

\subsection{Needs Analysis (NA)}


Strevens (1980) defines 'needs analysis' as "a procedure starting from the standpoint that is not 'general English' and that the learner (or his sponsor) can apply comprehensive information about the aims, purposes, needs, wants, roles, and functions for which English is required in his or her circumstances."

Moreover, Richards (1985) cites that needs analysis is the requirement of fact-finding or collecting data from various sources, such as the data about the learners, the materials, etcetera. Thus, the needs analysis phase of curriculum planning aims to determine for what a particular group of learners expects to use English and what their present level of competence.

Furthermore, Nunan (1988) defines needs analysis as a set of procedures for specifying a course of study parameters. Such parameters include the criteria and rationale for grouping learners, selecting and sequencing course content, methodology, and course length, intensity, and duration.

Brindley (1989) states that need analysis is finding out as much as possible before learning begins about the learners' current and future language use. Ellis and Johnson (1994) view that needs analysis is a method of obtaining a description of a learner's needs (or group of learner's needs). It will consider the specific purposes for which the learner will use the language, the kind of language to be used, the starting level, and the target level, which is to be achieved. The information is obtained from various people: company staff, trainers, and the learners themselves. It will have implications for the approach to training that will be taken. According to Robinson, 1991, it can be considered what the students themselves would like to gain from the language course. This view of needs implies that students may have personal aims and (or even in opposition to) the requirements of their studies or jobs.

\subsection{Islamic Economics (IES)}

There are many competing definitions of Islamic economics. The researcher would like to discuss several of them here. Hasannuzzaman is one of the first people who attempted to come up with a comprehensive definition: "Islamic economics is the knowledge and application of injunctions and rules of the Shariah that prevent injustice in the acquisition and disposal of material resources in order to provide satisfaction to human beings and enable them to perform their obligations to Allah and the society" (Hasanuzzaman 1984, 52).

This definition is quite vague. It does not specify which rules and knowledge are relevant to Islamic economics. Islamic economics is defined mainly by the concept of justice. It is unclear whether the author would consider capitalism or socialism as sound economic systems if modified to prevent injustice. For Mannan, the defining feature of Islamic economics is its values: "Islamic economics is a social science which studies the economic problems of a people imbued with the values of Islam" (Mannan, 1987).

However, he does not elaborate on the relevant values and how their involvement will create Islamic economics as a distinct field. For Ahmad, Islamic economics is "a systematic effort to understand the economic problem and man's behavior concerning that problem from an Islamic perspective" (Ahmad 1992, 19). Again, the definition does not hint at how the Islamic perspective requires Islamic economics to be distinct. Likewise, the following definitions portray Islamic economics as something shaped by Muslim scholars within the Islamic perspective but do not say how it differs in answering the core questions: "the Muslim thinkers' response to the economic challenges of their times. In this endeavor, they were aided by the Quran and the Sunnah and reason and experience (Siddiqi, 1992). Islamic economics is the representative Muslim's behavior in a typical Muslim society (Naqvi, 1994).

\section{Method}

\subsection{The Design}

This study used the descriptive research method. According to Arikunto (2006), the descriptive method is where the person doing the research presents it descriptively. The descriptive research designs enable the researcher to describe or present a picture of a phenomenon or phenomena under investigation. It is the opposite of another research methodology called analytical.

\subsection{Population and Sampling}

The population of this research is all of the students, English lecturers, Islamic economics lecturers, and stakeholders of the Islamic economics study program of the Muhammadiyah University of Bengkulu. The sample of this study was 50 people who divided into; 40 students and ten stakeholders.

\subsection{Instruments}

The first instrument is the 65 items of the questionnaire, adapted from Srabua (2007) and Kahf (2018). It was not tried out, the validity caused it, and the reliability of this instrument was tested. The researcher is making, 
adding, omitting, and revising based on the above sources and translated into Indonesian. The second instrument is the interview with ten stakeholders.

\subsection{Data Analysis}

The data of this study will analyze by using the various steps and formulas. The steps and formulas are weighted mean, interpretation of mean result based on Srabua (2007), percentage of frequency formula. Meanwhile, the data from the interviews in this study support and strengthen the questionnaire results data. Interviews are only given to stakeholders as additional data for the questionnaire to strengthen and support the results of the existing questionnaire.

\section{Results and Discussion}

\subsection{Results}

The result of this research showed the following tables:

Themes and topics

\begin{tabular}{llll}
\hline No & Themes/topics & Mean & Interpretation \\
\hline 1 & Relevance of Islamic economics & 3,96 & Maximally needed \\
2 & Definition of Islamic economics & 3,48 & Maximally needed \\
3 & Methodology of Islamic economics & 3,51 & Maximally needed \\
4 & Economic and other branches of knowledge & 3,28 & Neutral or moderately needed \\
\hline
\end{tabular}

Discourse Text

\begin{tabular}{|c|c|c|c|c|c|}
\hline No & \multicolumn{3}{|l|}{ Discourse texts } & Mean & Interpretation \\
\hline 1 & \multicolumn{3}{|c|}{ Facts and theories of Islamic economics } & 4,40 & Very maximally needed \\
\hline 2 & \multicolumn{3}{|c|}{ The existing bulk of the economics } & 4,20 & Maximally needed \\
\hline 3 & \multicolumn{3}{|c|}{ The economic problem } & 4,10 & Maximally needed \\
\hline 4 & \multicolumn{3}{|c|}{ Islam and economic activity } & 4,10 & Maximally needed \\
\hline 5 & \multicolumn{3}{|c|}{ The domain of religions and economics } & 4,00 & Maximally needed \\
\hline 6 & \multicolumn{3}{|c|}{ The relationship between Islamic and economics } & 4,00 & Maximally needed \\
\hline 7 & \multicolumn{3}{|c|}{$\begin{array}{l}\text { Comparison of the definition of economics between Islamic \& } \\
\text { western }\end{array}$} & 4,00 & Maximally needed \\
\hline 8 & \multicolumn{3}{|c|}{ The western paradigm of economics } & 4,00 & Maximally needed \\
\hline 9 & \multicolumn{3}{|c|}{ The historical background of Islamic economics } & 3,90 & Maximally needed \\
\hline 10 & \multicolumn{3}{|c|}{ Islamic paradigm of economics } & 3,90 & Maximally needed \\
\hline 11 & \multicolumn{3}{|c|}{ Definition of Islamic economics } & 3,90 & Maximally needed \\
\hline 12 & \multicolumn{3}{|c|}{ The proposed definition of Islamic economics } & 3,90 & Maximally needed \\
\hline 13 & \multicolumn{3}{|c|}{ The general methodology of Islamic economics } & 3,90 & Maximally needed \\
\hline 14 & \multicolumn{3}{|c|}{ Methodology and elaborating the Islamic economics system } & 3,90 & Maximally needed \\
\hline \multicolumn{6}{|c|}{$\overline{\text { Skills and sub-skills }}$} \\
\hline No & English Skills & Mean & \multicolumn{3}{|l|}{ Interpretation } \\
\hline 1 & Listening & 2,59 & \multicolumn{3}{|c|}{ Neutral or moderately needed } \\
\hline 2 & Speaking & 3,73 & \multicolumn{3}{|l|}{ Maximally needed } \\
\hline 3 & Reading & 1,82 & \multicolumn{3}{|l|}{ Minimally needed } \\
\hline 4 & Writing & 3,11 & \multicolumn{3}{|c|}{ Neutral or moderately needed } \\
\hline
\end{tabular}

4.2. Discussion

Due to the data result above, the result of this research describes briefly that interviews result are only given to stakeholders as additional data for the questionnaire to strengthen and support the results of the existing questionnaire. Ten stakeholders have been represented the all of the stakeholders. They have been the same answer the interview for the researcher, so they should be put on in the result section. The researcher 
indicates that there is a difference between students' perceptions and stakeholder perceptions. This is due to students who do not know the actual situation about what they need when they work later. At the same time, these stakeholder opinions are based on their experience during the work.

Finding out the need for English material of Islamic economics students of the Muhammadiyah University of Bengkulu is significant. This is in line with Basturkmen (2010), who stated that target situation analysis is a process to identify the learning tasks, activities, and skills learners will be using. However, investigating the most prioritized English Skill, English sub-skills, and English topics for Islamic economics students is very important. The data gathered explained that implementing the suitable English materials related to the terms of Islamic economics activities will positively impact the Islamic economics of the Muhammadiyah University of Bengkulu.

One of the similarities among those three groups of the sample was that speaking is an essential skill needed. It is an entire area of knowledge that has been stated to be the most important one by the three groups of a sample. This research revealed a result based on the communicative aspect of language. It was also found that speaking and listening are the most critical skills for the Islamic economics students of the Muhammadiyah University of Bengkulu.

This result is supported by Nurhazlinza (2015), who conducted research that found that communicative skills are the most critical skills in Islamic economics workplaces. In line with the productive lessons such as ticketing and guiding, the students are objected to having good ability in speaking, especially for their presentation and internship. Additionally, it confirmed the study conducted by Kuma (2010), who found that listening skills are the most prerequisite language skill that the students of both educational centers need to learn their subject areas studies followed by speaking, writing, and reading skills. The study's findings also identified speaking and listening skills as the most important language skills for the students' future occupation, followed by writing and reading skills.

Speaking skills have high importance for the students of Islamic economics of the Muhammadiyah University of Bengkulu because after graduating, they will interact with people in their daily world work. It is in line with Robinson (1991), who said that the students study English for study or work purposes. Therefore, it has implications for the kind of activities and topics on the course. The starting point, however, is the skills to be emphasized. Furthermore, in speaking sub-skills, fluency is the common sub-skills for all groups. McDonough and Shaw (1993) said that speaking skills materials should start from the premise that a communication purpose can be established in the classroom utilizing the information gap.

As an implication, practically for the students are to use this product of the study to develop their English skills to be useful for their future job especially in this global competition. The implication is for English lecturers to use the English materials to be learned and then use the developed materials to teach the students. Finally, the implication for theory is for the further researcher to use the result of the study as a reference in developing other materials related to English for Specific Purposes materials.

\section{Conclusion}

Due to the discussion above, the researcher concluded that: 1) The highest themes or topics needed by the students of the Islamic economics study program of the Muhammadiyah University of Bengkulu are theme about the methodology of Islamic 4,00\%. 2) The highest discourse texts needed by the students of the Islamic economics study program of the Muhammadiyah University of Bengkulu are Islam as a way of life $(4,60 \%)$ because the researcher found that from the questionnaire result. 3) The English skills needed by the Islamic economics study program of the Muhammadiyah University of Bengkulu. Speaking (3.74\%) is the most needed skill, the second skill needed is writing, followed by listening, and the last is reading.

\section{References}

Ahmad, K. (1992). Nature and significance of Islamic economics. In A. Ausaf, \& K. R. Awan (Eds.), Lectures on Islamic economics. Jeddah, KSA: IRTI, IDB.

Alwasilah, A. C. (1999). "Ímproving college English to function to the full." In Alwasilah, A. S. (2010). Language, culture, and education; A portrait of contemporary Indonesia. Bandung, IDN: Andira.

Araminta, L.D.W., \& Halimi, S.S. (2015). "ASEAN Economic Community 2015; needs analysis of Universitas Indonesia's Engineering Students", IJAL, 5(1).

Arikunto, S. (2006). Prosedur penelitian; suatu pendekatan praktis (research procedure; a practical approach). Bandung, IDN: Rineka Cipta.

Basturkmen, H. (2010). Developing courses in English for specific purposes. Macmillan, NY: Palgrave. 
Brindley, G. (1989). The role of needs analysis in adult ESL program design. In R.K. Johnson. (ed.). 1989. The second language curriculum. Cambridge, UK: Cambridge University Press.

Ellis, M., \& C. Johnson. (1994). Teaching business English. Oxford, UK: Oxford University Press.

Hasanuzzaman, SM. (1984). Definition of Islamic economics. Journal of Research in Islamic Economics

Hutchinson, T., \& A. Waters. 1987. English for specific purposes: a learner-centered approach. Cambridge, UK: Cambridge University Press.

Jordan, R. R. (1997). English for academic purposes. Cambridge, UK: Cambridge University Press.

Judd, E. L. (1981). Language policy, curriculum development, and TESOL instruction: a search for compatibility. TESOL Quarterly 15(1), 59-66.

Kahf, M. (2018). "Islamic economic materials." Retrieved from: http://monzer.kahf.com/papers/english/methodology malaysia.pdf on July 06, 2018.

Khalik, L. A. (2014). "ESP needs analysis based syllabus of economic faculty students, Universitas "45" Makassar," $2^{\text {nd }} I C E L$.

Kusni. (2007). "Reformasi perancangan program ESP di perguruan tinggi". Linguistik Indonesia. 25, (1). Retrieved

from: http://www.eli.org/Pages/current Issues.aspx?docname=/published docs/20111011 011153 835.pdf on November 3rd 2017.

Mackay, R. (1978). Identifying the nature of learners' needs. In R. Mackay and A. Mountford. (eds.). 1978. English for specific purposes. London, UK: Longman.

Mackay, R., \& A.J. Mountford. (1978). English for specific purposes: a case study approach. London: Longman Group Limited.

Mannan, M. A. I. (1987). Islamic economics: theory and practice. Boulder, UK: Westview Press.

McDonough, J., \& Shaw, C. (1993). Materials and methods in ELT. London, UK: Wiley Publishing.

Miyake, M., \& Tremarco, J. (2005). "Needs analysis for nursing students utilizing questionnaires and interviews," Kawasaki Journal of Medicine Welfare, 11(1).

Naqvi, S.N. H. (1994). Islam, economics, and society. London, Uk: Kegan Paul International.

Nunan, D. (1988). The learner-centered curriculum. Cambridge, UK: Cambridge University Press.

Richards, J.C. (1985). The context of language teaching. Cambridge, UK: Cambridge University Press.

Robinson, P. (1991). ESP today: a practitioner's guide. London, UK: Prentice-Hall.

Siddiqi, M. N. (1992). History of Islamic economic thought. In A. Ausaf, \& K. R. Awan (Eds.), Lectures on Islamic economics. Jeddah, KSA: IRTI, IDB.

Srabua, P. (2007). An analysis of needs and problems in the use of English for occupational purposes of hotels PR officers in Bangkok. Unpublished Thesis. Bangkok, THA: Graduate School, Kasetsart University.

Strevens, P. (1980). Teaching English as an international language. Oxford, UK: Pergamon Press. 